\title{
Climate justice in a carbon budget
}

\author{
Article
}

Accepted Version

McKinnon, C. (2015) Climate justice in a carbon budget. Climatic Change, 133 (3). pp. 375-384. ISSN 0165-0009 doi: https://doi.org/10.1007/s10584-015-1382-6 Available at https://centaur.reading.ac.uk/40496/

It is advisable to refer to the publisher's version if you intend to cite from the work. See Guidance on citing.

To link to this article DOI: http://dx.doi.org/10.1007/s10584-015-1382-6

Publisher: Springer

All outputs in CentAUR are protected by Intellectual Property Rights law, including copyright law. Copyright and IPR is retained by the creators or other copyright holders. Terms and conditions for use of this material are defined in the End User Agreement.

\section{www.reading.ac.uk/centaur}

\section{CentAUR}

Central Archive at the University of Reading

Reading's research outputs online 


\title{
Climate Justice in a Carbon Budget
}

\author{
Catriona McKinnon \\ Department of Politics and International Relations \\ University of Reading \\ Whiteknights \\ Reading RG6 6AA \\ United Kingdom \\ c.mckinnon@reading.ac.uk \\ +44(0) 1183878502 \\ Institute of Climate Change and Public Policy \\ Nanjing University of Information Science and Technology (NUIST) \\ 219 Ningliu Road, Pukou District \\ Jiangsu Province 210044 \\ China
}

Author biog:

Catriona McKinnon is Professor of Political Theory, and Director of the

Leverhulme Programme in Climate Justice, at the University of Reading. She is the author of Climate Change and Future Justice: Precaution, Compensation, Triage (Routledge 2011), and co-editor of Climate Change and Liberal Priorities (Routledge, 2012) and of The Ethics of Climate Governance (Rowman and Littlefield, forthcoming). She is currently writing a book about climate justice and international criminal law. 


\begin{abstract}
$\underline{\text { Abstract }}$
The fact of a carbon budget given commitment to limiting global-mean temperature increase to below $2^{\circ} \mathrm{C}$ warming relative to pre-industrial levels makes CO2 emissions a scarce resource. This fact has significant consequences for the ethics of climate change. The paper highlights some of these consequences with respect to (a) applying principles of distributive justice to the allocation of rights to emissions and the costs of mitigation and adaptation, (b) compensation for the harms and risks of climate change, (c) radical new ideas about a place for criminal justice in tackling climate change, and (d) catastrophe ethics.
\end{abstract}

Keywords: carbon budget; climate ethics; intergenerational justice; distributive justice; compensation; criminal justice; catastrophe ethics.

\title{
Climate Justice in a Carbon Budget
}

In their paper Knutti and Rogelj lay out fourteen facts supported by climate science showing $\mathrm{CO} 2$ emissions to be a scarce resource, given commitment to limiting global-mean temperature increase to below $2^{\circ} \mathrm{C}$ warming relative to preindustrial levels. These facts raise questions that require answers informed by ethics and political philosophy and - further on - the social sciences, in the search for feasible processes and institutions of equitable and effective climate governance.

In this paper I shall lay out a roadmap of approaches to climate justice given how the fact of the carbon budget brings future people within the scope of theories of climate justice. The roadmap will start with an outline of some well established approaches informed by distributive justice. Assuming that we can settle on a just allocation of emissions and costs that properly takes account of the claims of both present and future people, further questions of justice are raised given the carbon budget. First, what do those who exceed their allocation, or who fail to meet costs rightly assigned to them, owe to innocent people affected by these 
failures? Standardly, principles of corrective justice guide thinking about who owes what to whom when things go wrong in ways such as this, at any given point in time. The roadmap in the paper will highlight a new way in which these principles are fit to guide thinking about failures in the face of the carbon budget: that present people are liable to provide resources enabling satisfaction of possible compensation claims made by future people put at risk of harm by the failures of those present people. The second question of justice raised by failures to do what justice demands in the face of the carbon budget takes the roadmap into entirely new territory. When people act contrary to what is required by justice in ways that risk catastrophic consequences for innocent others, despite knowledge of the risks they create through their conduct, principles of criminal justice are activated. The paper will indicate a place of for criminal justice in the pantheon of our ethically informed approaches to climate change in the face of the carbon budget.

The facts identified by Knutti and Rogelj are as follows.

1. CO2 longevity: a large fraction of $\mathrm{CO} 2$ emitted stays in the atmosphere for centuries and longer.

2. The future effects of $\mathrm{CO} 2$ emissions are uncertain, and a large fraction of climate change caused by these emissions is irreversible insofar as that CO2 is not actively removed from the atmosphere.

3. The real warming commitment is the inertia of present infrastructures and practices which are not changing so as to reduce global CO2 emissions.

4. Every ton of $\mathrm{CO} 2$ emitted causes further warming.

5. The causal contribution made by countries and generations to past and future climate change is approximately in proportion to their total cumulative emissions.

6. Two thirds of the total $\mathrm{CO} 2$ budget in line with a $2{ }^{\circ} \mathrm{C}$ warming limit has already been emitted; at current emission rates, the budget will be depleted in around 30 years. 
7. There is a surplus of $\mathrm{CO} 2$ available in fossil fuel resources beyond the budget, which means that some carbon will have to remain in the ground, or be sequestered, in order to stay within the carbon budget.

8. There is uncertainty about the exact size of the carbon budget.

9. There have been great historical inequalities between countries in their cumulative $\mathrm{CO} 2$ emissions, and in the distribution of the benefits created by emissions.

10. Taking into account all drivers of climate change, historical contributions to it are very unevenly distributed over countries.

11. Achieving emissions reductions to remain within the carbon budget is a global collective action problem.

12. Present delays in mitigation efforts create greater mitigation burdens for subsequent generations.

13. Delays in mitigation are commonly justified by reference to a social discount rate. The choice of a social discount rate is an ethical choice reflecting the way in which future generations are valued by the current generation.

14. Geoengineering under a climate emergency also requires equitable solutions in theory and in practice.

Given how anthropogenic $\mathrm{CO} 2$ emissions do not remain at source but rather mingle evenly through the atmosphere, and given how climate change will damage (indeed-and is already causing - damage to the planet as a habitat for human beings (let alone other species), the fact that there is a carbon budget and that it is quickly being depleted (facts 4 and 6) brings climate change within the purview of philosophical theories of justice. In the context of a carbon budget the questions addressed by different families of (interconnected) theories are as follows.

(1) Distributive justice: ensure patterns of distribution of a moderately scarce good such that the benefits delivered by the good, and the burdens involved in maintaining the pattern, are justly shared by all parties in the 
distribution. ${ }^{1}$ Given a carbon budget, in present circumstances, the good to be distributed is emissions allocations and the burdens to be distributed are the costs created by mitigation and adaptation programmes. There are two things worth noting here. First, given that we will ultimately have to move to a zero carbon economy, emissions allocations will at some point transform from being a moderately scarce good to being an extremely scarce good (perhaps sooner than we think). In these circumstances it is not clear that principles of distributive justice continue to apply to emissions allocations. Second, following Henry Shue, what really matters from a moral point of view is that human energy needs are met (especially those of the global poor), and it is only contingently the case that emissions allocations do this (Shue 2013). These needs could be met by non carbon based energy production. Thus in a decarbonised global economy questions of distributive justice will still exist but will be refocused on the allocation of access to non-carbon based energy sources so as to ensure justice in the distribution of the benefits of this access and the costs of providing and maintaining it.

(2) Corrective justice: ensure that wrongs done are repaired. Theories of corrective justice contain principles of liability to connect those causing wrongful harm with those they harm in ways fit to support claims for compensation by the latter. ${ }^{2}$ In the context of a carbon budget, those who exceed their emissions allocations and/or fail to bear the costs of mitigation and adaptation that are rightfully theirs, are prima facie liable to provide compensation to innocent people suffering climate-related harmed as a result. Cases in tort law with this character are appearing in law courts with increasing frequency (Adam 2011). It is worth noting that although most accounts of liability under corrective justice specify negligence as a mens rea, not all do, and not for every tort. If liability for

${ }^{1}$ In modern times, the most famous theory of this type is John Rawls' 'justice as fairness' (Rawls 1971). Thinking about distributive justice from a philosophical perspective has a long history, and much contemporary political philosophy (at least in the Anglo-American tradition) is concerned with questions of distributive justice.

${ }^{2}$ An important book in this field is Coleman 1992. 
climate-related harms is strict - that is, if it does not depend on arguing that the defendant ought to have known the risks of climate related harm created by emissions - then excuses related to supposed uncertainty in climate science become irrelevant.

(3) Criminal justice: ensure the fair prosecution, trial and punishment of those who commit public wrongs. ${ }^{3}$ There is disagreement in theories of criminal justice about the purpose of punishment: retribution, deterrence, and the communication of fundamental norms of behaviour for a given community are all candidates. Thus far in the literature on climate justice, criminal justice has played no role. Later on in the paper I shall indicate a role it should play.

From the point of view of justice the picture is complicated by facts $(1,2,8,9,10$, 12 and 13) about the length of time CO2 remains in the Earth's atmosphere and thereby affects the climate. These facts make questions about justice in a carbon budget essentially intergenerational as well as intragenerational: members of any current temporal cohort in the community of humanity are capable of significantly and permanently damaging conditions of life for members of temporal cohorts not yet born, who are seriously vulnerable to the conduct of those who precede them, because time's arrow points in one direction only. Of course, it has always been the case that the past shapes the present and future. But the dawn of the Anthropocene has been marked by an unprecedented change to this feature of the human condition: scientific, technological, and industrial advances make most recent generations (at least in more developed countries) more powerful with respect to the future than has ever been true of any generation in human history. ${ }^{4}$ The facts about the atmospheric lifetime of CO2 combined with facts about the carbon budget make it necessary to think about climate justice from an intergenerational point of view. One influential account of the demands of intergenerational justice is given by John Rawls:

\footnotetext{
3 The philosophy of criminal justice is enjoying a renaissance at present. One could do no better than to start with Duff 2009.

4 The term 'Anthropocene' refers to a new epoch in the Earth's history in which human activity is, for the first time, having a significant global impact. See Crutzen and Stoermer 2000.
} 
intergenerational justice requires that social cooperation within any temporal cohort meets standards that any generation in time would have wanted all generations prior to it to have adopted and followed, and would want all generations subsequent to it to adopt and follow (Rawls 1993). Crudely, any generation ought to save and conserve in ways it would want every generation to save and conserve. ${ }^{5}$ If we combine a commitment to intergenerational justice with the philosophical theories of justice outlined above, what are the implications for life under a carbon budget?

With respect to distributive justice the first question is: what is a fair distribution of emissions allocations now given a requirement to ensure that future people are able to meet their energy needs? One prominent proposal is that emissions rights be given an equal distribution across all people, given the plausible claim that all people have equal rights to means enabling them to satisfy their energy needs (Jamieson 2005; Vanderheiden 2008; Singer 2002). One way to calculate equal per capita allocations would be to divide the amount of carbon remaining in the budget by the number of people currently alive. This is clearly flawed. First, it makes no provision for transition to non-carbon energy sources within the lifetimes of presently existing people; effectively, it would permit people in the current time slice to blow the carbon budget entirely leaving them with no means by which to satisfy their own future energy needs. (Of course, in this scenario, people would just continue to use carbon-based energy and blow the budget even more). Second, the proposal takes no account of the energy needs of future people. Consider how emissions allocations within a carbon budget would look if 1) a very large number of people will exist in the future and 2) all those future people's energy needs will require carbon intensive energy in order to be satisfied. If 1) and 2) are true then the fixed amount of carbon remaining in the budget (as Knutti and Rogelj make clear) has to be divided by a much larger

\footnotetext{
5 Rawls uses his famous 'veil of ignorance' to justify this principle as the one any person would choose if they did not know the particular generation to which they belong. For Rawls, this models the irrelevance of temporal location to any person's status as a being deserving of justice. Note that the claim does not imply that all generations are required to save at a uniform rate for the sake of later generations. (Rawls 1993).
} 
number of people than if we attended only to the carbon-based energy needs of present people. And this generates highly negative emissions allocations for present people. What this suggests is that if people in the present are to allocate equal rights to emissions with a positive value to present people, an equal per capita approach - insofar as it is justified by reference to the equal satisfaction of all persons' energy needs - commits them to the development of non-carbon based energy technologies that will ensure that future people's energy needs are as well satisfied as those of present people. ${ }^{6}$

The fact of the carbon budget means that ultimately total global emissions must reduce to zero: all moral arguments about climate change must be sensitive to this. This means that whatever initial distribution of rights to emissions allocations is justified there will come a point - sooner rather than later - at which these rights are trumped by the fact that the carbon budget is close to depletion. The moral parameters created by the fact of the carbon budget are evident in ethical arguments for differential emissions reductions pathways for different countries that, over time, converge to achieve the total reductions necessary to remain within the budget. They are also evident in arguments for the rapid development of zero carbon energy technologies, assuming that people have a basic human right to subsistence which cannot be met without development (Shue 1980). At present, most development is carbon intensive, and involves the creation of 'subsistence emissions' (Shue 1993). But such emissions are, as Shue puts it, an 'avoidable necessity' (Shue 1995)(as reflected in fact 3): they are necessary for people in developing economies to achieve the subsistence to which they have a basic human right, but this right could be met just as well (perhaps better?) by zero carbon development. Taking seriously the basic human right to subsistence in the face of the carbon budget makes it morally urgent to secure the energy needs of world's poor through low ultimately, and soon, zero - carbon development (Shue 2013).

\footnotetext{
${ }^{6}$ An extended discussion of the equal per capita view, and other issues related to distributive justice in the allocation of emissions see Caney 2012.
} 
This leads to the second question of distributive justice: what is a just distribution of the costs of mitigating and adapting to climate change, and of the development and implementation of zero-carbon energy technologies, within a carbon budget? Two key principles have received much attention. First, 'polluter pays': those who have contributed most to the problem are those who ought to bear the greatest burdens in addressing it. Given facts 9 and 10, the polluter pays principle would allocate higher absolute emissions reductions targets to countries in a more advanced state of development in virtue of their historically disproportionate emissions. But there are problems here. In particular, a temporal cohort in the Anthropocene located within a more developed country might object that they are being required to bear heavy burdens as a result of conduct not their own, for which they could not be held responsible, viz. the conduct of long dead countrymen who undertook development using fossil fuels. This temporal cohort might reasonably argue that any principle of justice governing relations between people across time must not impose burdens on those not responsible for causing the problem being addressed by the burdensome requirement.

A different approach which does not allocate burdensome requirements to address a problem by reference to causal contribution to the problem is the 'beneficiary pays' principle: those who have benefited from conduct causing the problem are those who ought to bear the costs of solving the problem, even when they have not caused the problem at all. According to this principle, people in more developed countries have benefited massively from their predecessors' emissions, and this is sufficient to require them to make higher emissions reductions (or to contribute more to global emissions reductions, if past development generated by fossil fuel has been replaced by relatively low carbon development). This approach requires a reliable method for identifying and measuring present benefits generated by past emissions. This is a challenge both from a causal perspective (to what extent can clear chains of causation linking present benefits to past emissions be disentangled from other causal chains?), 
and from a normative perspective (according to what theory of value does a change in a person's, or group's, conditions qualify as a benefit?). ${ }^{7}$

Furthermore, objections to this approach have, as with objections to the polluter pays approach, focused on the fairness of requiring people who are not responsible for a problem to bear the greatest costs associated with tackling it. Imagine that you go away on a three-month trip, and when you return you find that an uninvited skilful gardener has cultivated a flourishing vegetable patch in an unused bed in your garden, and that she died shortly thereafter, and before your return. You enjoy eating the vegetables, and your health is benefited. In cultivating the patch the gardener made liberal use of the village fertiliser stored in the barn, without realising that the supply is limited. Your neighbours, who have also been away on a three month trip, are now trying to get their vegetable patches established. On seeing your abundant crop, and learning of how it came about, they might make the following demands of you: (i) that you stop using any more of the limited supply of fertiliser; (ii) that you share your vegetable bounty with them, given that its existence is entirely dependent on the mystery gardener having used a disproportionate share of the fertiliser; and (iii) that you work hard with them to find new vegetable growing techniques that do not rely on fertiliser, given that it is fast running out. Advocates of the beneficiary pays principle must explain why your unrequested, but welcome, receipt of the vegetables generates an enforceable and non voluntary requirement for you to comply with some or all of demands (i)-(iii). ${ }^{8}$ And they must unpack the analogy in a convincing way. Eating freshly grown vegetables has clear, measurable

\footnotetext{
7 A promising approach to these questions draws on Sen and Nussbaum's 'capabilities' approach (Sen 1992). On this view, what matters, from a political point of view, for the assessment of advantage is not levels of welfare enjoyed, or amounts of resources owned or controlled, but rather the extent to which people are free to achieve well being, understood in terms of objective opportunities to do, and become, what they have reason to value.

8 Most people would think it would be very generous of you to act in the ways specified by the demands, but given the unreliability of generosity as a motive especially when the sacrifices involved relate to all the comforts and pleasures of living in a more developed country - what we really want are arguments to show that you can legitimately be compelled to make the sacrifices required to meet the demands.
} 
benefits for health. How do the products of carbon intensive development benefit people?

In general, Knutti and Rogelj note throughout their paper that climate change is a wicked problem. The global collective action needed to tackle it (fact 11), the uncertainty about the future effects of $\mathrm{CO} 2$ emissions (fact 2) and about the exact size of the carbon budget (fact 8), the possibility of climate catastrophes and the geoengineering agenda they would foreground (fact 14), and the difficulty of thinking through - from a moral and policy perspective - how to balance the rights and interests of present people against the rights and interests of future people (fact 13) all combine to make climate change a problem unprecedented in the history of ethics. A number of prominent climate ethicists have reflected on this. For example, Dale Jamieson argues that our existing ethical theories are inadequate to this unprecedented problem (Jamieson 2014). And Stephen Gardiner argues that the structure of the climate problem renders it a 'perfect moral storm' that presents the global rich and powerful in the present generation with various temptations to moral corruption; that is, to forms of argument and conduct that enable the global rich and powerful to continue to pursue their own interests while claiming to be (and perhaps even believing that they are) promoting climate justice (Gardiner 2011). ${ }^{9}$ This could have disastrous consequences for the world's poor, and for future people. Of particular salience here is his account of 'intergenerational buck passing' in climate policy-making, which amplifies fact 12: given a carbon budget, ineffective action on emissions reductions now creates a bigger emissions reductions burden for future people (Rogelj et al 2013). The temptation to pass the emissions reductions buck on to future generations may iterate down through subsequent generations, greatly enhancing the risk of climate catastrophe. And any generation in a state of climate emergency may reasonably react by burning more fossil fuels in an attempt to provide support and assistance to members of its cohort experiencing that emergency, which will then make the climate problem even worse for

9 He analyses the Kyoto Protocol in exactly these terms. 
subsequent generations who may react in a similar way, etc. Intergenerational buck passing may, Gardiner argues, create an intergenerational arms race. ${ }^{10}$

The demandingness of what we owe to future people in the face of present and past emissions is diluted in climate policy by the use of a social discount rate in calculating the costs of climate policies. The social discount rate places considerations of the costs of climate change to many future people outside the scope of policy. It does this by specifying a certain point in time (determined by the value of the discount rate) beyond which all costs approach zero. Use of a social discount rate in future oriented policy-making is ubiquitous in economic approaches. But the very choice to use a discount rate at all is a moral choice: it represents a decision to undertake a weighing of the interests of more distant future people against those of present people and less distant future people so as to prioritise the latter categories over the former. And weighing interests in this way, regardless of the temporal location of the interest holders, is a moral undertaking (fact 13. That is not to say that all forms of weighing are morally prohibited; perhaps there are good ethical reasons for committing to some forms of discounting (for example, of the commodities that future people will possess) and for rejecting others (for example, of future persons' well being) (Broome 2012). Furthermore, the value that is given to the discount rate is a way of representing the weight to be given to the interests of distant future people in present policy making, and so is an ethical choice in need of justification going well beyond mere reference to the present market interest rate (Broome 2012). Moral and political philosophers have been alive to these issues as economic approaches have ascended to the dominance they have presently and climate ethicists continue to resist the presentation of the discount rate as a value neutral and innocuous part of the toolkit of cost benefit analysis (Parfit 1992; Broome 1994; Ackerman 2008; Jamieson 2014; Gardiner 2011).

10 Gardiner argues that geoengineering presents significant opportunities for morally corrupt intergenerational buck passing. It enables the geoengineering generation to tell themselves that they are making a 'morally serious choice' by doing this instead of reducing emissions, when the reality is that the geoengineering generation will probably not have to bear any of the risks of implementing the technology, and will have increased the emissions reductions burden for subsequent generations (Gardiner 2011, 364). 
Debates about intergenerational distributive justice in the face of climate change conceptualise the Earth's absorptive capacity with respect to $\mathrm{CO} 2$ (up to the cap expressed in the carbon budget) as a good in need of fair distribution across all generations (which means, in effect, fair distribution across present and future generations, given that past emissions are unalterable). However, this way of thinking about the atmosphere has implications beyond distributive justice, for two other domains of justice that are well established in political philosophy: corrective justice, and criminal justice.

The commitment central to corrective justice is: repair wrongs done. Corrective justice requires that any party suffering wrongful harm as a result of the conduct of another has a justified claim of rectification which ought to be met by the harmer; most commonly, through the provision of compensation to the victim by the harmer (Coleman 1992). Demands for compensation in the name of corrective justice are now regularly made in the intragenerational context, and are likely to proliferate as the impacts of climate change worsen (Farber 2008; Hunter and Salzman 2007). However, corrective justice can also have intergenerational scope: it can connect members of the present generation to as yet unborn future people in a relationship of liability for reparation, and this has significant consequences for what present people owe to future people given the fact of a carbon budget.

Under corrective justice in the intragenerational context, an agent becomes liable for providing compensation only when what she does causes harm: prior to the causation of harm, there is no liability. However, there are good reasons to think that liability under corrective justice ought also to respond to the imposition of impermissible risk. Here, we can think of an agent imposing impermissible risk as ipso facto liable for providing the means for compensation which can be accessed by any future people for whom the risk ripens into a harm (McKinnon 2011). With respect to climate justice, this interpretation of corrective justice enables us to claim that insofar as its $\mathrm{CO} 2$ emissions create impermissible risks for future people, the present generation is required to make provision for the 
compensation that will be owed to future people if the risks the present generation is imposing mature into harms for those people. Given the fact of a carbon budget, the present generation's failure to date to radically reduce global CO2 emissions imposes impermissible risks on future people; the harmful consequences for future people of business-as-usual are well documented. In addition, and not sufficiently well noted, is the way in which the risks being imposed on future people by present people not only relate to basic human rights, but also to future people's capacities to act ethically with respect to the people who will follow them (fact 12). By passing the CO2 emissions reduction buck to future people, we might - as Gardiner notes - blight their lives by putting them in a position wherein whatever they do, they will do wrong (Gardiner 2011: 389).

There are well founded worries about how compensation schemes for climate change harms and risks could function in practice so as to distribute 'permits to pollute': so long as an agent is willing and able to provide for compensation for those harmed by the climate change caused by their emissions, they may continue with business as usual. Crudely, the global rich get to continue as they are. ${ }^{11}$ What these worries make clear is that any set of principles of intergenerational climate justice must contain principles that prohibit certain types and rates of emissions, and activity fit to exacerbate these emissions, regardless of the willingness and ability of the emitter to provide compensation. These prohibitions will be set by reference to the carbon budget, and the ideal distribution of emissions allowances across generations, given progression towards a zero carbon global economy in order to remain within the budget. Given the importance to the temporally extended political community of humanity of not exceeding this budget, these prohibitions have great moral significance for all generations. The domain of justice concerned with the commission of 'public wrongs' - that is, conduct violating standards of the greatest moral significance to any community - is criminal justice. Could philosophical theories of criminal justice be brought to bear in the context of he carbon budget?

11 These worries also apply to offsetting schemes (Hyams and Fawcett 2013). 
The only attempt in the literature to do this is my work-in-progress on using international criminal law to address reckless conduct that creates risks of human extinction. I call this a law of 'postericide'.12 This work develops arguments for the idea that a new international crime of postericide is a morally required response to humanity's changed circumstances in the Anthropocene, given the carbon budget. Postericide is:

Intentional or reckless conduct systematically and seriously threatening the extinction - or near extinction - of humanity.

International criminal law contains no precedents for the prosecution of postericide. But, I argue, the normative commitments at the heart of international criminal law commit us to revising it in ways that make it fit for human life in the Anthropocene. Here in the Anthropocene it is in our power to permanently damage or destroy conditions on Earth for all those who will live after us.

Now consider the following conception of international criminal law. In an international context we are accountable to one another as human political animals. When a state fails to do what it ought to do for us qua political animals when it fails to perform the functions according to which its existence is justified, i.e. the delivery of justice - then our shared membership of the community of human political animals generates the following responsibilities. First, a responsibility to those who are affected by their state's abuse of its powers, or its failure to offer them protection from attack by others; that is, a responsibility to victims of international crimes. And second, a responsibility to those who commit these crimes - whether they be agents of the state, or independent agents acting in the vacuum of a failed state - to use international criminal law to

\footnotetext{
12 McKinnon, 'Climate Change as Postericide', Leverhulme Trust Research Fellowship 2014-16, grant number RF-2014-021/8.
} 
prosecute them. ${ }^{13}$ Here, international criminal law is a declaration of our commitment as members of the community of human political animals to protect the institutional conditions we need to live well together.

It is now a short (but certainly not uncontroversial) step to the conclusion that international criminal law ought to govern present conduct insofar as it creates serious and systematic extinction risks. The reason for this is we are in political community with future people. Taking seriously the idea of international criminal law as an expression of what human beings owe to one another regardless of their location in space, this body of law ought also to protect all human beings regardless of their location in time. Given the carbon budget, if groups in the presently existing temporal cohort egregiously exceed their allocations and do not make concentrated and resolute efforts to develop zero carbon energy technologies, and if they are aware of the extinction risks their conduct creates, then they are liable for postericide. Who might these groups be? Fossil fuel companies and states obstructing meaningful action on climate change are the obvious candidates.

Summing up, the facts foregrounded by Knutti and Rogelj have great significance for debates about what we owe to one another, and to future people, in the name of justice. In particular, the fact of the carbon budget, and the uncertainty surrounding its value and the consequences of exceeding it, bring present CO2 emissions within the scope of pedigreed debates about justice now being extended to generate obligations to future people. These obligations are, without exception, extremely demanding; and the structure of the climate change problem presents people here and now - in this crucial moment in history (fact 6) - with many tempting opportunities to duck these obligations by continuing to emit à la business as usual (fact 3, fact 7). One way this is sometimes attempted is with spurious claims that the science does not support the assumptions forming the background against which justice based arguments are made. Another route to inaction that refers to climate science cites the substantial uncertainties about the carbon budget (fact 8) - what it is, how much

13 This line of argument draws on ideas in Luban 2004 and Duff 2010. 
is left, etc. - as justifying political inaction with respect to local and global emissions reductions. This is clearly not justified from an ethical point of view. On the contrary - as Knutti and Rogelj insist, and for a range of reasons delivered by ethically informed reflection on the implications of depleting the carbon budget - our continuing uncertainty provides us with more, not fewer, urgent reasons to act to reduce global emissions.

To end, let me reflect upon the direction of travel that philosophical thinking about justice might have to take if we deplete the carbon budget. Although there is no certainty about this (fact 2), the atmospheric lifetime of $\mathrm{CO} 2$ (fact 1) and its contribution to continued warming regardless of what point in history any ton of it is emitted (fact 4) means that business as usual puts future people at risk of catastrophic climate change, creating an extreme scarcity of resources necessary for survival at local, and possibly global, scales. Contemporary theories of justice, and their ancestors in the Anglo-American tradition, work with a background assumption of moderate scarcity only: few enough resources to make the fair and principled management of competition for them necessary, but not so few that such management ceases to be justified or feasible. Catastrophic climate change could change all this. Under climate catastrophe, what is required are not principles of justice but rather principles of triage. Most familiar from medical ethics, and battlefield medicine, principles of triage sort people into various categories, and state priority rules for the distribution of resources to people in different categories. In a world beyond the carbon budget, and in which climate catastrophes happen, the language of justice may be entirely misplaced. Principles of triage understood as principles to guide the allocation of extremely scarce survival resources at the macro level, and understood as distinct from principles of justice, are severely under theorised in contemporary moral and political philosophy (McKinnon 2011). In addition to owing future people compensation for harms ripening from risks we impose on them now by barrelling towards depletion of the carbon budget, it may be that we also owe them an intellectual inheritance in the form of an ethics for climate catastrophe. 
I am very grateful to Reto Knutti and Joeri Rogelj for their comments on earlier drafts of this paper. Comments made by Dominic Roser and two anonymous referees for the journal also greatly helped to improve the paper.

\section{$\underline{\text { References }}$}

Adam, D. (2011), 'Climate Change in Court', Nature Climate Change 1, May 2011, 127-130.

Ackerman, F. (2008), Can We Afford the Future? The Economics of a Warming World. London: Zed Books.

Broome, J. (1994), 'Discounting the Future', Philosophy and Public Affairs 23(2), 128-56.

Broome, J. (2012), Climate Matters. New York: W.W. Norton.

Caney, S. (2005), 'Cosmopolitan Justice, Responsibility and Global Climate Change', Leiden Journal of International Law 18(4), 747-75.

Caney, S. (2012), 'Just Emissions', Philosophy and Public Affairs 40(4), 255-300.

Coleman, J. (1992), Risks and Wrongs. Oxford: Oxford University Press.

Cowen, T. and Parfit, D. (1992), 'Against the Social Discount Rate'. In: Laslett, P. and Fishkin, J.S. (eds.) Justice Between Age Groups and Generations. New Haven: Yale University Press.

Crutzen, P. J., and E. F. Stoermer (2000). 'The 'Anthropocene", Global Change Newsletter 41: 17-18.

Duff, R.A. (2009), Answering for Crime: Responsibility and Liability in the Criminal Law. Oxford: Hart.

Duff, R.A. (2010), 'Authority and Responsibility in International Criminal Law' in S. Besson and J. Tasioulas (eds), The Philosophy of International Law. Oxford: Oxford University Press.

Farber, D.A. (2008), 'The Case for Climate Compensation: Doing Justice to Climate Change Victims in a Complex World', Utah Law Review 2, 1-36. Gardiner, S.M. (2011), A Perfect Moral Storm: The Ethical Tragedy of Climate Change, Oxford: Oxford University Press. 
Hunter, D. and Salzman, J. (2007), 'Negligence in the Air: The Duty of Care in Climate Change Litigation'. University of Pennsylvania Law Review 155(6), 174194.

Hyams, K. and Fawcett. T. (2013), 'The Ethics of Carbon Offsetting', Wiley Interdisciplinary Reviews: Climate Change, 4(2), 91-8.

Jamieson, D. (2005), 'Adaptation, Mitigation, and Justice'. In: Sinnott-Armstrong, W. and Howarth, R.B. (eds), Perspectives on Climate Change: Science, Economics, Politics, Ethics. Amsterdam: Elsevier.

Jamieson, D. (2014), Reason in a Dark Time: Why the Struggle Against Climate Change Failed, and What It Means for our Future. Oxford: Oxford University Press. Luban, D. (2004), 'A Theory of Crimes Against Humanity', Yale Journal of International Law 29, 85-167.

McKinnon, C. (2011), Climate Change and Future Justice: Precaution, Compensation and Triage. London: Routledge.

Meyer, L. and Roser, D. (2006), 'Distributive Justice and Climate Change: The Allocation of Emission Rights', Analyse und Kritik 28, 223-49.

Page, E. (2011), 'Climatic Justice and the Fair Distribution of Atmospheric Burdens: A Conjunctive Account', The Monist 94(3), 412-32.

Rawls, J. (1971). A Theory of Justice. Oxford: Oxford University Press.

Rawls, J. (1993), Political Liberalism. New York: Columbia University Press. Rogelj J., McCollum D.L., O'Neill B.C., Riahi K. (2013), '2020 emissions levels required to limit warming to below $2^{\circ} \mathrm{C}^{\prime}$. Nature Climate Change 3:405-412. Sen, A. (1992), Inequality Reexamined. Oxford: Oxford University Press.

Shue, H. (1980), Basic Rights: Subsistence, Affluence and U.S. Foreign Policy. Princeton, N.J.: Princeton University Press.

Shue, H. (1993), 'Subsistence Emissions and Luxury Emissions', Law and Policy 15(1), 39-59.

Shue, H. (1995), 'Avoidable Necessity: Global Warming, International Fairness, and Alternative Energy'. In: Shapiro, I. and Wagner DeCew, J. (eds) Theory and Practice: NOMOS XXXVII. New York: NYU Press, 239-64.

Shue, H. (2013), 'Climate Hope: Implementing the Exit Strategy', Chicago Journal of International Law 13(2), 381-402. 
Singer, P. (2002), One World: The Ethics of Globalisation. New Haven, Conn.: Yale University Press).

Vanderheiden, S. (2008), Atmospheric Justice: A Political Theory of Climate Change. Oxford: Oxford University Press. 